\title{
A MULTICLASS METHOD FOR THE ANALYSIS OF ANTIBIOTIC RESIDUES IN MILK POWDER AND WHEY POWDER BY UPLC-MS/MS
}

\author{
Arzu Yavuz ${ }^{*}$ İsmail Azar, Ali Özcan, Niyazi Ülkü \\ Veterinary Drug Residue Department, Central Research Institute of Food and Feed Control, Bursa, Turkey \\ Received / Geliş: 14.09.2021; Accepted / Kabul: 21.12.2021; Published online / Online bask1: 20.01.2022 \\ Yavu₹, A., Azar, İ., Özcan, A., Ülkü, N. (2022). A multiclass method for the analysis of antibiotic residues in milk \\ powder and whey powder by UPLC-MS/MS. GIDA (2022) 47 (1) 25-33 doi: 10.15237/gida.GD21124.
}

Yavuz, A., Azar, İ., Özcan, A., Ülkü, N. (2022). Süt tozu ve peyniraltı suyu tozunda antibiyotik kalıntılarının UPLC-MS/MS ile analizinde çoklu grup yöntemi. GIDA (2022) 47 (1) 25-33 doi: 10.15237 /gida.GD21124.

\begin{abstract}
An ultra-performance liquid chromatography-tandem mass spectrometry (UPLC-MS/MS) multi-class method was developed and validated for the determination of 27 antibiotic residues from five classes (macrolides, sulfonamids, quinolones, lincosamids, diaminopyrimidines) in milk powder and whey powder which are commonly used as raw material of many products in the food industry. A simple, inexpensive and fast sample preparation based on the extraction of samples with methanol is the main advantage of the validated method. The validation of the method was performed following the requirements outlined in the European Commission Decision 2002/657/EC, which is required procedure for the methods used in analysis of official audits samples in Europe and Turkey. Matrix effect and uncertainties related with sample preparation and instrumental analysis were minimised by using matrix-matched calibration. The method is capable of detecting residues at very low concentrations.
\end{abstract}

Keywords: antibiotics, residues, UPLC-MS/MS, validation, milk powder, whey powder, 2002/657/EC

\section{SÜT TOZU VE PEYNİRALTI SUYU TOZUNDA ANTİBIYYOTIKK KALINTILARININ UPLC-MS/MS İLE ANALİZİNDE ÇOKLU GRUP YÖNTEMİ}

\section{ÖZ}

Gıda endüstrisinde birçok ürünün hammaddesi olarak yaygın bir şekilde kullanılan süt tozu ve peyniraltı suyu tozunda beş gruptan (makrolidler, sülfanamidler, kinolonlar, linkozamidler, diaminopirimidinler) 27 antibiyotik kalıntısının belirlenmesi için bir ultra-performans sıvı kromatografisi-tandem kütle spektrometrisi (UPLC-MS/MS) çok sınıflı bir yöntem geliştirilmiş ve valide edilmiştir. Valide edilmiş bu yöntemin ana avantaj1, metanol ile numunelerin ekstraksiyonuna dayanan basit, ucuz ve hızlı numune hazırlamadır. Yöntemin validasyonu, Avrupa ve Türkiye'deki resmi denetim numunelerinin analizinde kullanılan yöntemler için gerekli prosedür olan 2002/657/EC sayılı Avrupa Komisyonu Kararında belirtilen gereklilikler izlenerek gerçekleştirilmiştir. Matriks uyumlu kalibrasyon kullanılarak, numune hazırlama ve enstrümantal

\footnotetext{
${ }^{*}$ Corresponding author / Yazışmalardan sorumlu yazar

17: arzu.yavuzyilmaz@tarimorman.gov.tr

Arzu Yavuz; ORCID no: 0000-0002-2526-4761 İsmail Azar; ORCID no: 0000-0003-4424-208X

Ali Özcan; ORCID no: 0000-0002-1338-7852

Niyazi Ülkü; ORCID no: 0000-0003-3139-8827
}

(ग): (+90) 2242464720

且: (+90) 2242461941 
analiz ile ilgili matriks etkisi ve belirsizlikler minimize edilmiştir. Yöntem, kalıntıları çok düşük konsantrasyonlarda tespit etme yeteneğine sahiptir.

Anahtar kelimeler: antibiyotikler, kalıntılar, UPLC-MS/MS, validasyon, süt tozu, peyniraltı suyu tozu, 2002/657/EC

\section{INTRODUCTION}

In animal husbandry, the use of antibiotics as to enhance efficiency and to promote animal growth was banned in EU countries and in Turkey since 2006, because of a risk to human health (European Commission, 2005; Ministry of Agriculture and Rural Affairs, 2006). This situation has created undesirable effects such as increased animal infections and decreased animal production, and the total amount of antibiotic use in animals increased due to the significant increase in therapeutic antibiotic and disinfectant use (Cheng et al., 2014). These antibiotics can cause residues in animal origin foods consumed by humans. Consumption of foods containing these residues poses many risks to public health, particularly development of antibiotic resistance, hypersensitivity reaction, carcinogenicity, mutagenicity, teratogenicity, and disruption of intestinal normal flora (Beyene, 2016). These risks emerge the importance of monitoring animal origin foods in terms of antibiotic residues. Although sensitive and reliable analytical methods for the determination of veterinary drugs in food of animal origin are strongly required to ensure food safety, multiclass methods for veterinary drugs are still limited (Dasenaki and Thomaidis, 2015).

In the European Union, the Maximum residue limits (MRL) of antibiotics in foods are determined by the Commission Regulation 37/2010 / EC (European Commission, 2010). The requirements for performance and validation of analytical methods employed in the official residues control are determined by European Decision 2002/657/EC (European Commission, 2002). Turkey legislation is also compatible with these regulations of the European Union.

In the national residue control plans, mostly the primary products are monitored in Europe and in Turkey. However, processed foods derived from products containing antibiotic residues are outside the control plans, thus posing a risk to food safety. Methods that enable the monitoring of antibiotic residues in processed foods are important tools to ensure food safety by allowing these foods to be included in the National Control Plans.

Whey and milk powder, which have high nutritional value, are used in the production of many foods from floury foods to meat products, from dairy foods to chocolate and confectionery in order to improve the textural properties of foods (Coronado et al., 2002; Secchi et al, 2011; Liang and Hartel, 2004; Barbut, 2006; Serdaroğlu, 2006; González-Martınez et al, 2002). In addition, in recent years, the determination of their positive effects on health has led to the widespread use of whey powder and milk powder in the field of food supplements and functional food production (Hoppe et al., 2008; Ramos et al, 2015; Helkar et al., 2016). So, in order to protect public health, it is necessary that monitoring antibiotic residue in milk powder and whey powder.

Today LC-MS/MS, which has high selectivity and sensitivity, is the most common technique used in the detection and quantification of veterinary drug residues (Blasco et al., 2007; Moretti et al., 2017; Dasenaki and Thomaidis, 2015). The current trend in drug residue analysis is the development of multiple methods that can monitor a wide variety of compounds belonging to different classes. Although published methods for detecting antibiotic residue in milk are relatively abundant, there are a limited number of published studies to detect antibiotic residues in milk powder by LC-MS/MS. Yu and Hu (2012) developed a method of C18-stir bar sorptive extraction (SBSE)-high performance liquid chromatography (HPLC)-tandem mass spectrometry (MS/MS) for the determination of six sulfonamids in milk and milk powder samples. Rezende et al. (2012) developed a method involving ethyl acetate extraction and C-18 dispersive solid phase clean up for the determination of chloramphenicol and florfenicol 
in liquid milk, milk powder and bovine muscle by LC-MS/MS and validated it according to the 2002/657/EC decision in liquid milk matrix. A comprehensive study was performed by Dasenaki and Thomaidis (2015) and a method was developed which can determine a wide range of veterinary drugs and pharmaceutical residues in milk powder, butter, fish tissue and eggs using LC-MS/MS with a quite long extraction procedure that includes steps such as ultrasonic bath, defatting with hexane, placing for 12 hours at $-23{ }^{\circ} \mathrm{C}$. A method involving acetonitrile extraction and lipid-removing SPE column Oasis PRiME HLB for the determination of 61 veterinary drugs in milk and milk powder by UPLC-MS/MS was developed by Tian et al. (2016) and in validation, parameters such as linearity and precision were evaluated according to $2002 / 657 /$ EC criteria.

In this study, a simple, fast and inexpensive multiresidue method was validated for the detection of antibiotic residues in whey powder and milk powder which are used as raw material in a wide range of food products. Within the scope of the validated method, 6 parameters from macrolide group, 11 parameters from sulfonamid group, 9 parameters from quinolone group, 1 parameter from lincosamid group, 1 parameter from diaminopyrimidine, totally 27 veterinary drugs were analyzed in whey powder and milk powder. The method is based on the extraction of samples with methanol and the determination and calculation of the residues in the extract by LCMS/MS. Two product ions obtained from the fragmentation of the molecular ion determined for each analyte were used at the identification of analytes by LC-MS/MS. The highest intensities ions were used for quantification, and the other ions were used for confirmation. The ratios and retention times of the selected ions were also taken into account in the identification of the analytes. Matrix-matched calibration standards were used by the analysis of spiked blank matrix samples to compensate matrix effect. This is the most widely used approach to compensate for signal suppression experienced during MS/MS analysis (Shendy et al., 2016). Since milk powder and whey powder do not have the maximum residue limits defined in the regulations, the focus was on determining the lowest levels of each analyte that could be detected. And within the scope of the method, the ability to detect analytes at very low values has been obtained. A validation limit (VL) has been defined considering the lowest detectable concentration value for the analytes. And recovery, repeatability and reproducibility studies were performed at three levels, 1, 1.5 and 2 times the VL. Statistical evaluation of all parameters studied was carried out in accordance with the requirements of the Commission Decision 2002/657/EC of the European Union and the results were found within the appropriate value ranges.

\section{MATERIALS AND METHODS}

\section{Chemicals and reagents}

Erytromycin, Sarafloxacin Hydrochloride, Spiramycin, Tilmicosin, Tylosin, Sulfachloropyridazine, Sulfadiazine, Sulfadimethoxine, Sulfadoxine, Sulfamerazine, Sulfamethazine, Sulfamethoxazole, Sulfapyridine, Sulfathiazole, Sulfaquinoxaline, Trimethoprim, Ciprofloxacin Hydrochloride, Danofloxacin Mesylate, Difloxacin Hydrochloride, Enrofloxacin, Erytromycin, Flumequine, Marbofloxacin, Nalidixic Acid, Oxolinic Acid were obtained from Dr. Ehrenstorfer $\mathrm{GmbH}$ (Augsburg, Germany). Neospiramycin, Tylvalosin were obtained from TRC (Toronto, Canada). LC-MS grade methanol, formic acid supplied by Merck (Darmstadt, Germany). Ammonium formate (AF) ( $\geq 99 \%$ ) was from Fluka (Buchs, Switzerland, Ultrapure water was produced by using Water Purification System; Elga, Purelab Option Q7.

\section{Equipment}

An UPLC-ESI-MS/MS instrument, consisted of a Waters Acquity Ultra-Performance LC with a Waters column manager and heater/cooler, binary system manager, sample manager coupled to a Waters XEVO TQD triple quardrupole mass spectrometer equipped with an electrospray ionization (ESI) source (Waters Corp., Milford, MA, USA) was used for mass spectrometric detection. Chromatographic 
separation was effected with BEH C18 $1.7 \mu \mathrm{m}$ 2.1x50 mm Column.

\section{Sample preparation}

$5 \pm 0.1 \mathrm{~g}$ of sample was weighed in a $50 \mathrm{~mL}$ centrifuge tube. $15 \mathrm{~mL}$ methanol was added and vortexed for $15 \mathrm{~min}$. Then the tube centrifuged for $5 \mathrm{~min}$ at $10000 \mathrm{rpm} .7 \mathrm{~mL}$ of the supernatant was transferred to a clean glass centrifuge tube and dried at $50{ }^{\circ} \mathrm{C}$ in Nitrogen Turbo Evaporator (Biotage, TurboVap ${ }^{\circledR L V}$ ). The residue was reconstituted with $1 \mathrm{~mL}$ of 50:50 Mobile phase A: Mobile phase B followed by vortex-mixing for 2 min and centrifuged for $5 \mathrm{~min}$ at $10000 \mathrm{rpm}$. The supernatant was filtered through a $0.22 \mu \mathrm{m}$ syringe filter into an HPLC vial. Five microliters of the sample was injected into the LC-MS/MS.

\section{Instrument conditions}

Water containing $0.1 \%$ formic acid and $0.1 \mathrm{mM}$ ammonium formate (A) and methanol containing
$0.1 \%$ formic acid and $0.1 \mathrm{mM}$ Ammonium formate (B) was utilised as the mobile phase. The gradient conditions were employed as follows: 0 $2 \mathrm{~min}, 1-1 \% \mathrm{~B}$; 2.0-8.0 min, 1-95\% B; 8.0-9.0 $\min , 95-95 \% \mathrm{~B} ; 9.01-12.0 \mathrm{~min}, 1-1 \% \mathrm{~B}$. The flow rate was set at $0.2 \mathrm{~mL} / \mathrm{min}$ and column oven temperature was $60^{\circ} \mathrm{C}$.

The analyses were performed in electrospray ionization (ESI) positive ion mode using a multiple reaction monitoring (MRM) for quantitative for data acquisition. The mass parameters were as follows: desolvation gas flow, $1000 \mathrm{~L} \mathrm{~h}^{-1}$; desolvation temperature, $500^{\circ} \mathrm{C}$; cone gas flow; cone voltage, $50 \mathrm{~V}$; capillary voltage, 3.5 $\mathrm{kV}$; source temperature, $150^{\circ} \mathrm{C}$; extractor voltage, $3 \mathrm{~V}$.

The optimized MRM parameters can be found in Table 1.

Table 1. Optimized parameters of the LC-MSMS system for the 27 selected antibiotics

\begin{tabular}{|c|c|c|c|c|c|c|c|c|c|}
\hline Group & Name & $\begin{array}{l}\text { Dwell } \\
\text { time(s) }\end{array}$ & $\begin{array}{c}\text { Molecular } \\
\text { Ion }\end{array}$ & $\begin{array}{l}\text { Cone } \\
\text { (V) }\end{array}$ & $\begin{array}{l}\text { Product } \\
\text { ion } 1\end{array}$ & $\begin{array}{l}\text { Collision } \\
\text { (V) }\end{array}$ & $\begin{array}{l}\text { Product } \\
\text { ion } 2\end{array}$ & $\begin{array}{l}\text { Collision } \\
\text { (V) }\end{array}$ & $\begin{array}{l}\text { Retention } \\
\text { time } \\
(\mathrm{min})\end{array}$ \\
\hline \multirow[t]{9}{*}{ Quinolones } & Ciprofloxacin & 0.005 & 332.1 & 42 & 288.1 & 18 & 314.1 & 22 & 4.55 \\
\hline & Danofloxacin & 0.005 & 358.2 & 38 & 96.0 & 25 & 314.1 & 20 & 4.57 \\
\hline & Difloxacin & 0.005 & 400.3 & 30 & 356.2 & 20 & 382.2 & 20 & 4.76 \\
\hline & Enrofloxacin & 0.005 & 360.3 & 25 & 316.3 & 20 & 342.3 & 20 & 4.60 \\
\hline & Flumequine & 0.005 & 262.1 & 35 & 202.0 & 15 & 244.0 & 25 & 6.24 \\
\hline & Marbofloxacin & 0.005 & 363.1 & 35 & 72.0 & 20 & 320.0 & 15 & 4.30 \\
\hline & Nalidixic Acid & 0.005 & 233.1 & 30 & 187.0 & 25 & 215.0 & 15 & 6.11 \\
\hline & Oxolinic Acid & 0.005 & 262.0 & 32 & 216.0 & 30 & 244.0 & 19 & 5.52 \\
\hline & Sarafloxacin & 0.005 & 386.2 & 45 & 299.1 & 27 & 342.1 & 18 & 4.81 \\
\hline \multirow[t]{10}{*}{ Sulfonamides } & Sulfachloropyridazine & 0.005 & 285.1 & 32 & 92.0 & 28 & 156.0 & 15 & 4.75 \\
\hline & Sulfadiazine & 0.005 & 251.0 & 30 & 92.0 & 27 & 156.0 & 15 & 3.78 \\
\hline & Sulfadimethoxine & 0.005 & 311.1 & 36 & 92.0 & 32 & 156.0 & 20 & 5.47 \\
\hline & Sulfadoxine & 0.005 & 311.0 & 35 & 92.0 & 32 & 156.0 & 15 & 5.04 \\
\hline & Sulfamerazine & 0.005 & 265.1 & 35 & 92.0 & 25 & 156.0 & 15 & 4.29 \\
\hline & Sulfamethazine & 0.005 & 279.1 & 35 & 124.1 & 25 & 186.0 & 15 & 4.67 \\
\hline & Sulfamethoxazole & 0.005 & 254.1 & 30 & 92.0 & 25 & 156.0 & 15 & 4.77 \\
\hline & Sulfapyridine & 0.005 & 250.0 & 33 & 108.0 & 25 & 156.0 & 16 & 4.05 \\
\hline & Sulfaquinoxaline & 0.005 & 301.1 & 32 & 92.2 & 30 & 156.1 & 16 & 5.58 \\
\hline & Sulfathiazole & 0.005 & 256.0 & 31 & 92.0 & 25 & 156.0 & 15 & 3.85 \\
\hline Diaminopyrimidines & Trimethoprim & 0.005 & 291.3 & 40 & 123.0 & 30 & 230.2 & 30 & 4.41 \\
\hline \multirow[t]{6}{*}{ Macrolides } & Spiramycin & 0.005 & 422.3 & 30 & 100.9 & 22 & 174.0 & 22 & 5.37 \\
\hline & Tilmicosin & 0.005 & 869.6 & 94 & 132.0 & 52 & 174.0 & 50 & 5.86 \\
\hline & Tylosin & 0.005 & 916.5 & 74 & 100.9 & 50 & 174.1 & 42 & 6.45 \\
\hline & Tylvalosin & 0.005 & 1042.6 & 80 & 108.9 & 80 & 174.0 & 80 & 7.11 \\
\hline & Erytromycin & 0.005 & 734.5 & 30 & 158.1 & 30 & 576.5 & 20 & 6.46 \\
\hline & Neospiramycin & 0.005 & 699.5 & 58 & 142.1 & 26 & 174.1 & 28 & 5.18 \\
\hline Lincosamides & Lincomycin & 0.005 & 407.2 & 40 & 126.1 & 25 & 359.3 & 20 & 4.45 \\
\hline
\end{tabular}




\section{Validation}

Validation of the method for detection and quantitative analysis of analytes was carried out according to the the requirements outlined in Commission Decision 2002/657/EC applicable to all analyzes (veterinary medicines, pesticides, minerals, etc.) of animal products (EC 2002). In this validation study, limit of detection (LOD) and limit of quantification (LOQ), Linearity, Trueness/Recovery, Precision (Repeatability, Reproducibility), specificity/selectivity and ruggedness parameters were performed. The matrix-matched extraction procedure was used.

\section{Linearity}

The linearity of calibration curves was evaluated by using a five-level matrix matched calibration curve for all analytes. Blank samples were spiked with working standards to obtain the five concentration levels listed in Table 2 for each analyte. Peak areas were used as the analytical response versus concentrations for all target compounds. As the results given in Table 3, acceptable linear regression values $(\mathrm{r} 2>0.99)$ were obtained for all target analytes over the concentration range for the matrix matched calibration curves of milk powder and whey powder.

Table 2. Linear range and concentration levels of each analyte

$\begin{array}{ccccccc}\text { Analyte } & \text { Linear range } & \text { Level 1 } & \text { Level 2 } & \text { Level 3 } & \text { Level 4 } & \text { Level 5 } \\ & \mu \mathrm{g} / \mathrm{kg} & \mu \mathrm{g} / \mathrm{kg} & \mu \mathrm{g} / \mathrm{kg} & \mu \mathrm{g} / \mathrm{kg} & \mu \mathrm{g} / \mathrm{kg} & \mu \mathrm{g} / \mathrm{kg}\end{array}$

\begin{tabular}{lcccccc}
\hline Ciprofloxacin & $5-30$ & 5 & 8 & 12 & 16 & 30 \\
\hline Danofloxacin & $5-30$ & 5 & 8 & 12 & 16 & 30 \\
\hline Difloxacin & $5-30$ & 5 & 8 & 12 & 16 & 30 \\
\hline Enrofloxacin & $5-30$ & 5 & 8 & 12 & 16 & 30 \\
\hline Erytromycin & $0.5-3$ & 0.5 & 0.8 & 1.2 & 1.6 & 3 \\
\hline Flumequine & $5-30$ & 5 & 8 & 12 & 16 & 30 \\
\hline Lincomycin & $2.5-15$ & 2.5 & 4 & 6 & 8 & 15 \\
\hline Marbofloxacin & $5-30$ & 5 & 8 & 12 & 16 & 30 \\
\hline Nalidixic Acid & $5-30$ & 5 & 8 & 12 & 16 & 30 \\
\hline Neospiramycin & $1.5-9$ & 1.5 & 2.4 & 3.6 & 4.8 & 9 \\
\hline Oxolinic Acid & $5-30$ & 5 & 8 & 12 & 16 & 30 \\
\hline Sarafloxacin & $5-30$ & 5 & 8 & 12 & 16 & 30 \\
\hline Sulfachloropyridazine & $2.5-15$ & 2.5 & 4 & 6 & 8 & 15 \\
\hline Sulfadiazine & $2.5-15$ & 2.5 & 4 & 6 & 8 & 15 \\
\hline Sulfadimethoxine & $2.5-15$ & 2.5 & 4 & 6 & 8 & 15 \\
\hline Sulfadoxine & $2.5-15$ & 2.5 & 4 & 6 & 8 & 15 \\
\hline Sulfamerazine & $2.5-15$ & 2.5 & 4 & 6 & 8 & 15 \\
\hline Sulfamethazine & $2.5-15$ & 2.5 & 4 & 6 & 8 & 15 \\
\hline Sulfamethoxazole & $2.5-15$ & 2.5 & 4 & 6 & 8 & 15 \\
\hline Sulfapyridine & $2.5-15$ & 2.5 & 4 & 6 & 8 & 15 \\
\hline Sulfaquinoxaline & $2.5-15$ & 2.5 & 4 & 6 & 8 & 15 \\
\hline Sulfathiazole & $2.5-15$ & 2.5 & 4 & 6 & 8 & 15 \\
\hline Spiramycin & $0.5-3$ & 0.5 & 0.8 & 1.2 & 1.6 & 3 \\
\hline Tilmicosin & $0.5-3$ & 0.5 & 0.8 & 1.2 & 1.6 & 3 \\
\hline Trimethoprim & $2.5-15$ & 2.5 & 4 & 6 & 8 & 15 \\
\hline Tylosin & $0.5-3$ & 0.5 & 0.8 & 1.2 & 1.6 & 3 \\
\hline Tylvalosin & $0.5-3$ & 0.5 & 0.8 & 1.2 & 1.6 & 3 \\
\hline & & & & & &
\end{tabular}


Table 3. Linearity and recovery results of analytes for milk powder and whey powder

\begin{tabular}{|c|c|c|c|c|c|c|c|c|}
\hline \multirow{3}{*}{ Analyte } & \multicolumn{4}{|c|}{ Milk powder } & \multicolumn{4}{|c|}{ Whey powder } \\
\hline & \multirow[b]{2}{*}{ Linearity } & \multicolumn{3}{|c|}{ Recovery $(\%)$} & \multirow{2}{*}{ Linearity } & \multicolumn{3}{|c|}{ Recovery $(\%)$} \\
\hline & & Level 2 & Level 3 & Level 4 & & Level 2 & Level 3 & Level 4 \\
\hline Ciprofloxacin & 0.995 & 92.4 & 99.9 & 91.9 & 0.998 & 98.1 & 102.9 & 100.9 \\
\hline Danofloxacin & 0.994 & 95.9 & 94.0 & 98.3 & 0.991 & 100.0 & 101.0 & 97.8 \\
\hline Difloxacin & 0.995 & 97.5 & 102.3 & 98.9 & 0.993 & 98.9 & 105.3 & 102.2 \\
\hline Enrofloxacin & 0.999 & 98.1 & 101.9 & 101.6 & 0.998 & 97.1 & 104.3 & 99.5 \\
\hline Erytromycin & 0.992 & 98.0 & 100.9 & 103.7 & 0.992 & 101.7 & 97.8 & 95.5 \\
\hline Flumequine & 0.996 & 99.7 & 108.9 & 102.5 & 0.997 & 99.7 & 108.9 & 102.5 \\
\hline Lincomycin & 0.995 & 93.7 & 99.5 & 98.0 & 0.997 & 93.4 & 104.7 & 100.4 \\
\hline Marbofloxacin & 0.997 & 96.5 & 98.3 & 100.0 & 0.995 & 98.0 & 99.8 & 102.3 \\
\hline Nalidixic Acid & 0.993 & 97.9 & 105.1 & 102.3 & 0.993 & 98.7 & 106.3 & 102.2 \\
\hline Neospiramycin & 0.991 & 93.0 & 99.5 & 100.1 & 0.990 & 97.4 & 100.8 & 97.7 \\
\hline Oxolinic Acid & 0.997 & 96.0 & 103.8 & 102.1 & 0.995 & 101.2 & 106.4 & 102.7 \\
\hline Sarafloxacin & 0.993 & 98.0 & 101.7 & 99.4 & 0.990 & 98.3 & 104.0 & 101.7 \\
\hline Sulfachloropyridazine & 0.992 & 99.8 & 103.6 & 98.5 & 0.991 & 100.2 & 102.6 & 99.0 \\
\hline Sulfadiazine & 0.992 & 102.4 & 101.6 & 101.4 & 0.990 & 95.5 & 100.9 & 99.5 \\
\hline Sulfadimethoxine & 0.993 & 102.8 & 100.8 & 99.6 & 0.992 & 100.6 & 100.7 & 101.8 \\
\hline Sulfadoxine & 0.995 & 100.4 & 98.9 & 93.5 & 0.997 & 100.5 & 102.3 & 101.0 \\
\hline Sulfamerazine & 0.995 & 103.8 & 98.3 & 104.5 & 0.992 & 100.3 & 100.7 & 100.8 \\
\hline Sulfamethazine & 0.996 & 106.4 & 97.4 & 103.9 & 0.997 & 100.9 & 99.4 & 99.7 \\
\hline Sulfamethoxazole & 0.999 & 103.0 & 102.0 & 102.8 & 0.995 & 98.0 & 101.3 & 100.9 \\
\hline Sulfapyridine & 0.993 & 103.5 & 106.1 & 98.9 & 0.997 & 102.0 & 106.3 & 101.4 \\
\hline Sulfaquinoxaline & 0.996 & 100.4 & 96.9 & 91.5 & 0.997 & 100.7 & 101.8 & 100.7 \\
\hline Sulfathiazole & 0.997 & 102.0 & 101.0 & 97.8 & 0.997 & 90.9 & 103.1 & 98.5 \\
\hline Spiramycin & 0.991 & 85.4 & 99.6 & 101.6 & 0.990 & 97.1 & 96.0 & 99.2 \\
\hline Tilmicosin & 0.990 & 95.6 & 105.0 & 89.4 & 0.991 & 99.0 & 100.8 & 91.6 \\
\hline Trimethoprim & 0.993 & 100.0 & 100.7 & 96.0 & 0.992 & 96.0 & 100.9 & 103.2 \\
\hline Tylosin & 0.990 & 93.9 & 99.2 & 99.3 & 0.991 & 100.8 & 106.9 & 99.6 \\
\hline Tylvalosin & 0.994 & 101.5 & 104.0 & 100.1 & 0.994 & 96.2 & 102.4 & 103.0 \\
\hline
\end{tabular}

\section{Trueness}

The trueness of the method was evaluated using recovery analyses of each analyte in milk powder and whey powder at 1, 1.5, 2 times the VL, (the second-third and fourth concentration levels in Table 2) 6 replicates. Matrix matched calibration curves were used for the evaluation of the recoveries obtained from analyses. Recoveries were calculated as a ratio between the determined concentration and the real concentration. Appropriate recoveries were obtained with the range of 85.4-108.9\% for milk powder and 90.9$108.9 \%$ for whey powder as it seen in Table 3 .
Precision (repeatability and within-laboratory reproducibility)

The precision of this method was showed in term of repeatability (intra-day precision) and withinlaboratory reproducibility (inter-day precision), which were expressed as the relative standard deviation (RSD) values of set of 6 replicate spiked samples analysis at three different levels in 3 days. Six blank milk powders were spiked with working standard mix for each level, at 1, 1.5, 2 times the $\mathrm{VL}$ and analysed. This process repeated three days. In addition, as suggested by Kaufmann, (2009) one set of data was analysed for the other 
matrix (whey powder) covered by the analytical method. A sample set was prepared in 6 parallel with blank whey powders, spiked with analyte mix at the same three levels $(1,1.5,2$ times the VL) and analysed. The obtained RSD values of the within-laboratory reproducibility were found below $10 \%$ for the three fortified levels and all measurements did not exceed the acceptable values calculated from the Horwitz equation. These results indicate the sufficient precision of the developed method.

\section{$L O D, L O Q$}

For calculation of LOD and LOQ, the standard deviation (SD) of 20 independent measurements of blank samples fortified at the lowest level of calibration were used. Three times of obtained SD was calculated as LOD and ten times of obtained SD was calculated as LOQ. Very low levels of LOD and LOQ values were calculated especially for analytes in the macrolide group. The obtained values can be found in Table 4 .

Table 4. LOD, LOQ, $C C \alpha$ and $C C \beta$ values

\begin{tabular}{lcc} 
Analyte & $\begin{array}{c}\text { LOD } \\
\mu \mathrm{g} / \mathrm{kg}\end{array}$ & $\begin{array}{c}\text { LOQ } \\
\mu \mathrm{g} / \mathrm{kg}\end{array}$ \\
\hline Ciprofloxacin & 1.24 & 4.13 \\
\hline Danofloxacin & 1.91 & 6.37 \\
\hline Difloxacin & 1.02 & 3.40 \\
\hline Enrofloxacin & 0.76 & 2.54 \\
\hline Erytromycin & 0.22 & 0.73 \\
\hline Flumequine & 1.02 & 3.40 \\
\hline Lincomycin & 0.53 & 1.75 \\
\hline Marbofloxacin & 1.94 & 6.46 \\
\hline Nalidixic Acid & 1.68 & 5.59 \\
\hline Neospiramycin & 0.62 & 2.08 \\
\hline Oxolinic Acid & 0.80 & 2.67 \\
\hline Sarafloxacin & 1.75 & 5.84 \\
\hline Sulfachloropyridazine & 0.48 & 1.60 \\
\hline Sulfadiazine & 0.53 & 1.78 \\
\hline Sulfadimethoxine & 0.49 & 1.63 \\
\hline Sulfadoxine & 0.38 & 1.26 \\
\hline Sulfamerazine & 0.63 & 2.10 \\
\hline Sulfamethazine & 0.46 & 1.52 \\
\hline Sulfamethoxazole & 0.52 & 1.74 \\
\hline Sulfapyridine & 0.88 & 2.92 \\
\hline Sulfaquinoxaline & 0.42 & 1.40 \\
\hline Sulfathiazole & 0.84 & 2.8 \\
\hline Spiramycin & 0.19 & 0.63 \\
\hline Tilmicosin & 0.23 & 0.78 \\
\hline Trimethoprim & 0.52 & 1.72 \\
\hline Tylosin & 0.23 & 0.78 \\
\hline Tylvalosin & 0.20 & 0.67 \\
\hline & &
\end{tabular}

\section{Specificity / selectivity}

The selectivity of the method was evaluated by the analysis of 20 blank milk powder samples. The absence of any peaks at the retention times of the target analytes indicated that there was no matrix interference that could lead to false positive signals.

\section{Ruggedness}

The method was evaluated in terms of ruggedness against changes in Centrifuge Speed in Centrifuge Time, Solvent Brand, Evaporation Temperature, Extraction Vortex Time,

Vortex Time After Evaporation, Filter Brand parameters. Approach of Youden was used in the evaluation as indicated in 2002/657/EC (EC 2002). It was determined that there was no significant change at the results.

\section{CONCLUSION}

Low-cost, low-solvent consumption and speed are prioritised factors in the multiresidue methods development and the developed method has met all of these priorities. The validation results are in accordance with the European Commission Decision 2002/657/EC. Acceptable validation parameters such as linearity, recovery, precision and LOQs were obtained. It is clear that the present method is capable of detecting low amounts of residues when considering calculated LODs in the range of $0.19 \mu \mathrm{g} / \mathrm{kg}-6.37 \mu \mathrm{g} / \mathrm{kg}$. The validation results showed that this method is suitable for the determination of antibiotic residues in milk powder and whey powder.

The present method is accredited under ISO 17025 by the Turkish Accreditation Agency (TURKAK) and will allow the control of antibiotic residues in milk powder and whey powder to be included in National Residue Control Plans.

\section{CONFLICT OF INTEREST}

The authors declare no conflict of interest.

\section{AUTHOR CONTRIBUTION}

İ.A. A.Ö and A.Y. designed the research. N.Ü, A.Ö. and İ.A. performed the validation. A.Y., I.A and N.Ü. analyzed the data. A.Y. prepared the 
manuscript. İ.A. edited the manuscript. All authors approved the submitted version.

\section{REFERENCES}

Beyene, T. (2016). Veterinary drug residues in food-animal products: its risk factors and potential effects on public health. $J$ Vet $S_{c i}$ Technol, 7(1), 1-7.

Barbut, S. (2006). Effects of caseinate, whey and milk powders on the texture and microstructure of emulsified chicken meat batters. LWT-Food Sci Technol, 39(6), 660-664.

Blasco, C., Picó, Y., Torres, C. M. (2007). Progress in analysis of residual antibacterials in food. TrAC Trends in Anal Chem, 26(9), 895-913.

Cheng, G., Hao, H., Xie, S., Wang, X., Dai, M., Huang, L., Yuan, Z. (2014). Antibiotic alternatives: The substitution of antibiotics in animal husbandry? Frontiers in microbiol, 5, 217.

Coronado, S. A., Trout, G. R., Dunshea, F. R., Shah, N. P. (2002). Antioxidant effects of rosemary extract and whey powder on the oxidative stability of wiener sausages during 10 months frozen storage. Meat Sci, 62(2), 217-224.

Dasenaki, M. E., Thomaidis, N. S. (2015). Multiresidue determination of 115 veterinary drugs and pharmaceutical residues in milk powder, butter, fish tissue and eggs using liquid chromatographytandem mass spectrometry. Anal Chimica Acta, 880, 103-121

European Commission. (2002). Commission Decision 2002/657/EC of 12 August 20022 implementing council directive 96/23/EC concerning the performance of analytical methods and the interpretation of results. Off $J$ Eur Community, L 221:8-36

European Commission. (2005). Ban on antibiotics as growth promoters in animal feed enters into effect. https://ec.europa.eu/commission/presscorner/ detail/en/IP_05_1687 (Accessed: 25 May 2020)

European Commission. (2010). 37/2010/EC, on pharmacologically active substances and their classification regarding maximum residue limits in foodstuffs of animal origin. Official J European Community. L15 (2010) 1-72.

González-Martınez, C., Becerra, M., Cháfer, M., Albors, A., Carot, J. M., Chiralt, A. (2002). Influence of substituting milk powder for whey powder on yoghurt quality. Trends in Food Sci Technol, 13(9-10), 334-340

Helkar, P. B., Sahoo, A. K., Patil, N. J. (2016). Review: Food industry by-products used as a functional food ingredients. Int $J$ Waste Resources, 6(3), 1-6.

Hoppe, C., Andersen, G. S., Jacobsen, S., Mølgaard, C., Friis, H., Sangild, P. T., Michaelsen, K. F. (2008). The use of whey or skimmed milk powder in fortified blended foods for vulnerable groups. J nutr, 138(1), 145S-161S.

Kaufmann, A. (2009). Validation of multiresidue methods for veterinary drug residues; related problems and possible solutions. Analytica chimica acta, 637(1-2), 144-155.

Liang, B., Hartel, R. W. (2004). Effects of milk powders in milk chocolate. J Dairy Sci, 87(1), 2031.

Ministry of Agriculture and Rural Affairs. (2006). Communique Amending the Communique on the Production, Import, Export, Sale and Use of Feed Additives and Premixes (Tebliğ No: 2006/1) (RG:21.01.2006 Say1:2656)

Moretti S., Saluti G. and Galarini, R. (2017). Residue determination in honey. In: Honey analysis, De Toledo V. A. (eds.), Intech Open p. 325365

Ramos, Ó. L., Pereira, R. N. C., Rodrigues, R. M. M., Teixeira, J. A., Vicente, A. A., Malcata, F. X. (2015). Whey and whey powders: Production and uses. Food Science Encyclopaedia of Food and Health pp: 498-505.

Rezende, D. R., Filho, N. F., Rocha, G. L. (2012). Simultaneous determination of chloramphenicol and florfenicol in liquid milk, milk powder and bovine muscle by LC-MS/MS. Food Additives \& Contaminants: Part A, 29(4), 559-570

Secchi, N., Stara, G., Anedda, R., Campus, M., Piga, A., Roggio, T., Catzeddu, P. (2011). 
Effectiveness of sweet ovine whey powder in increasing the shelf life of Amaretti cookies. LWT-Food Sci Technol, 44(4), 1073-1078.

Shendy, A. H., Al-Ghobashy, M. A., Alla, S. A. G., Lotfy, H. M. (2016). Development and validation of a modified QuEChERS protocol coupled to LC-MS/MS for simultaneous determination of multi-class antibiotic residues in honey. Food chem, 190, 982-989.

Serdaroğlu, M. (2006). Improving low fat meatball characteristics by adding whey powder. Meat Sci, 72(1), 155-163.
Tian, H., Wang, J., Zhang, Y., Li, S., Jiang, J., Tao, D., Zheng, N. (2016). Quantitative multiresidue analysis of antibiotics in milk and milk powder by ultra-performance liquid chromatography coupled to tandem quadrupole mass spectrometry. J chromatography B, 1033, 172-179.

Yu, C., Hu, B. (2012). C18-coated stir bar sorptive extraction combined with high performance liquid chromatography-electrospray tandem mass spectrometry for the analysis of sulfonamides in milk and milk powder. Talanta, 90, 77-84. 